\title{
Adefovir dipivoxil modulates cytokine expression in Th1/Th2 cells in patients with chronic hepatitis B
}

\author{
RONG-LI PIAO, YUAN-YUAN LIU, DAN TIAN, ZHEN-HUA MA, \\ MANLI ZHANG, CHONG ZHAO and JUN-QI NIU
}

Department of Gastroenterology, The First Hospital of Jilin University, Changchun 130021, P.R. China

Received May 23, 2011; Accepted September 12, 2011

DOI: $10.3892 / \mathrm{mmr} .2011 .627$

\begin{abstract}
The impact of adefovir dipivoxil (ADV) treatment on the immune system in patients with chronic hepatitis $\mathrm{B}(\mathrm{CHB})$ is unknown. The present study was designed to determine the expression of six cytokines, IL- 2 , IFN- $\gamma$, TNF- $\alpha$, IL-4, IL-6 and IL-10, and their correlation with liver functions and clinical responses to $\mathrm{ADV}$ treatment. A total of $22 \mathrm{CHB}$ patients were treated with ADV at a daily oral dose of $10 \mathrm{mg}$. Six cytokines, as well as AST, ALT and HBV DNA levels in blood samples were quantified prior to and following the treatment. A total of 10 healthy volunteers were enrolled as the control group. The six cytokines in CHB patients were significantly lower than in healthy individuals, and were increased significantly following 4, 12 and 24 weeks of ADV treatment. Although ALT, AST and HBV DNA were reduced following treatment, no correlation was found between these six cytokines and liver function or HBV DNA levels. The levels of the six cytokines in the group of patients with a complete clinical response were significantly higher than those in the group with a partial clinical response. ADV treatment increases the immunity of Th1/Th2 cells in $\mathrm{CHB}$ patients, and the increases in cytokines partly reflect the efficacy of the antiviral treatment.
\end{abstract}

\section{Introduction}

Chronic hepatitis $\mathrm{B}(\mathrm{CHB})$ poses a major health problem, with more than 350 million individuals being infected worldwide (1), of whom 120 million are in China (2). Without effective treatment, $\mathrm{CHB}$ may lead to cirrhosis, hepatocellular carcinoma and mortality. CHB is the result of a complex interaction between a replicating non-cytopathic virus and a down-regulated anti-viral immune response of the patient. Strong humoral and cellular immune responses are required for complete recovery

Correspondence to: Dr Yuan-Yuan Liu, Department of Gastroenterology, The First Hospital of Jilin University, 71 Xinmin Street, Changchun, Jilin 130021, P.R. China

E-mail: liuyuanyuan1960@163.com

Key words: adefovir dipivoxil, chronic hepatitis B, flow cytometry, interleukin (IL)-2, interferon- $\gamma$, tumor necrosis factor- $\alpha$, IL-4, IL-6, IL-10 from CHB (3). Therefore, there is an increasing interest in investigating the host immune response to antiviral therapy in order to develop novel therapeutic approaches or to improve clinically available agents. In addition, careful analysis of the host immune response to therapeutics may lead to personalized therapy in CHB patients.

Adefovir dipivoxil (ADV) is an oral prodrug of adefovir, an analogue of adenosine monophosphate; its active intracellular metabolite, adefovir diphosphate, inhibits HBV DNA polymerase at levels much lower than those required to inhibit human DNA polymerases (1). More importantly, ADV shows a favorable response in patients with lamivudine-resistant $\mathrm{HBV}$ infection (4). ADV has been approved for the treatment of chronic HBV infection $(5,6)$. It has been shown that ADV at a $10 \mathrm{mg}$ oral daily dose reduces serum HBV DNA and alanine aminotransferase (ALT) levels and increases the rates of hepatitis B e-antigen ( $\mathrm{HBeAg}$ ) seroconversion, which has a favorable risk-benefit profile for long-term treatment (5). Therefore, the dose regimen has been broadly used in the treatment of $\mathrm{CHB}$ patients, including in HBV-HIV-1-coinfected patients (7).

Since HBV is a non-cytopathic virus, cell-mediated immunity (CMI) appears to be responsible for the viral clearance and the elimination of $\mathrm{HBV}$-infected hepatocytes. T-cell responses are very weak in CHB patients (8). There are two subclasses of $\mathrm{T}$ helper cells based on the pattern of cytokines they secrete (9), Th1 and Th2 cells, that have been found to regulate human immune systems through differentially producing cytokines. For instance, Th1 cells produce cytokines, including interleukin (IL)-2, interferon (IFN)- $\gamma$ and tumor necrosis factor- $\alpha$ (TNF- $\alpha$ ), that activate cytotoxic $\mathrm{T}$ lymphocytes to promote cell-mediated immunity and clearance of virus-infected cells; and therefore, a decreased level of these cytokines may facilitate the progression of chronic HBV infection $(10,11)$. By contrast, Th2 cells produce different cytokines, including IL-4, IL-5, IL-6, IL-10 and IL-13. These cytokines contribute to the regulation of humoral immunity against extracellular pathogens, and thus have a significant role in viral persistence (12-14). Different cytokines have various functions in regulating humoral and cellular immune responses. For example, IFN- $\gamma$ preferentially inhibits the proliferation of Th2 cells, while IL-4 and IL-10 down-regulate the secretion of IL-12, which is the critical cytokine for Th1 differentiation (15). IL-6 is a multifunctional cytokine largely responsible for the hepatic response to infections or systemic 
inflammation; its concentration in the serum is associated with chronic liver inflammation (16).

There are an increasing number of studies exploring the expression profiles of Th1/Th2 cytokines in CHB patients $(8,17)$. In those studies, the cytokine profiles of peripheral blood mononuclear cells associated with $\mathrm{CHB}$ were analyzed by RT-PCR, indicating that the production of IFN- $\gamma$ by hepatitis B surface antigen ( $\mathrm{HBsAg}$ )-reactive cells is associated with hepatocyte damage (8). However, the impact of ADV treatment on Th1/Th2 cytokines in $\mathrm{CHB}$ patients remains unknown. The aim of this study was to explore the cytokine expression profiles of Th1/Th2 cells in the peripheral blood of CHB patients prior to and during ADV therapy. The cytokines analyzed were IL- 2 , IFN- $\gamma$, TNF- $\alpha$, IL-4, IL- 6 and IL-10. We also conducted the correlation analyses between cytokine levels and liver function, and viral load in these patients. It is hoped that our results would not only help optimize ADV therapy for $\mathrm{CHB}$, but also facilitate antiviral drug discovery and development for CHB in general.

\section{Materials and methods}

Patients and healthy volunteers. A total of $22 \mathrm{CHB}$ patients (17 male and 5 female) were enrolled into the clinical trial of ADV (GlaxoSmithKline, UK). The patients were diagnosed with $\mathrm{CHB}$, but had neither cirrhosis nor were hepatitis B carriers, according to the Chinese Hepatitis B Prevention Guide, which was drafted by the Chinese Medical Association of Hepatology and Chinese Medical Association of Infection Disease and Parasites in 2005. These CHB patients were all positive for HBsAg and $\mathrm{HBeAg}$, and had a serum HBV DNA level of at least 1,000 copies/ml and a serum ALT level of at least 1.3 times the upper limit of the normal range. All the patients were negative in a serum test for HIV and hepatitis $\mathrm{C}$ and $\mathrm{D}$ virus. The exclusion criteria also included a presence or history of hepatocellular carcinoma (HCC), decompensated liver disease or autoimmune hepatitis, and lamivudine or other antiviral therapies within 3 months prior to screening. In addition, 10 healthy volunteers (6 male and 4 female, 45.1 \pm 6.57 years of age) with HBeAg-negative and normal ALT $(<40 \mathrm{U} / \mathrm{l})$ were enrolled into this study as controls; all of them had not been treated with any agents with possible activity impacting immune function, such as glucocorticoids, within 3 months prior to screening.

Study design. The Institutional Review Board of the First Hospital of Jilin University, China, reviewed and approved this study and informed consent was obtained from each of the 22 patients who received $10 \mathrm{mg}$ of adefovir dipivoxil per day for 6 months or longer. The cytokines of Th1/Th2, HBV DNA level and biochemical markers of liver function [ALT and aspartate aminotransferase (AST)] were analyzed prior to and 4, 12 and 24 weeks following ADV therapy. Healthy volunteers did not receive any treatment and provided blood samples for analysis. ALT and AST were quantified by IFCC methods $(18,19)$. Clinical data were collected, monitored and entered into a database by Quintiles.

Virology assessment. Serum HBsAg and anti-HBe antibody were determined by an enzyme-linked immunosorbent assay
(ELISA), following the manufacturer's instruction (Roche, Shanghai, China). Anti-HDV and anti-HIV antibodies were screened with ELISA kits (Shenzhen PG Biotech, China). Serum HBV DNA was determined using a HBV real-time PCR detection kit (Shenzhen PG Biotech; detection limit $1 \times 10^{3}$ copies $/ \mathrm{ml}$ ) according to the manufacturer's instructions.

Immunocytochemistry. For quantification of cell surface IL-2, IFN- $\gamma$, TNF- $\alpha$, IL-4, IL-6 and IL-10 on CD8(+) T-lymphocytes, blood samples were collected in sterile, heparin-filled blood collection tubes. Whole blood $(350 \mu \mathrm{l})$ was diluted with an equal amount of Iscove's modified Dulbecco's medium (IMDM; Bao Biotechnology Co., Ltd., Shanghai, China), and then incubated with phorbol myristoyl acetate (PMA; Sigma, St. Louis, MO, USA), monensin (Sigma) and ionomycin (Sigma) for $4 \mathrm{~h}$ at $37^{\circ} \mathrm{C}$. Half of the cells collected were assayed with peridinin chlorophyll-protein (PerCP)-conjugated anti-CD3-antibodies (4 $\mu \mathrm{l}$; Caltag, Burlingame, CA, USA) and fluorescein-isothiocyanate (FITC)-conjugated anti-CD8-antibodies (4 $\mu \mathrm{l}$; Caltag), another half of the cells were assayed with PerCP-conjugated anti-CD3-antibodies (4 $\mu \mathrm{l}$; Caltag) and R-phycoerythrin (PE)-conjugated anti-CD8-antibodies (4 $\mu$; Caltag). The mixtures were incubated for $30 \mathrm{~min}$ at room temperature (RT; $\sim 25^{\circ} \mathrm{C}$ ). The cells were further divided into six tubes, and subsequently fixed with $80 \mu 1$ of Reagent A (fixative; Caltag) for $30 \mathrm{~min}$ at RT and washed with $3 \mathrm{ml}$ of phosphate-buffered saline (PBS) by centrifugation at $300 \mathrm{x}$ g for $5 \mathrm{~min}$. After adding $80 \mu \mathrm{l}$ of Reagent B (Caltag) to lyse erythrocytes, cells were incubated with $1.5 \mu \mathrm{l}$ of one of the antibodies of anti-IL-6, IFN, IL-4, IL-10, TNF and IL-2, respectively, for $30 \mathrm{~min}$ at RT. All the cells were washed with $3 \mathrm{ml}$ of PBS by centrifugation at $300 \mathrm{x}$ g for $5 \mathrm{~min}$, and then resuspended with $0.5 \mathrm{ml}$ PBS for FACS analysis. All reactions following the addition of antibodies were conducted in the dark.

Flow cytometry. Fluorescence was analyzed with a 488-nm fluorescence activated sorter (FACSCalibur; BD Biosciences, Salt Lake City, UT, USA). T-lymphocytes were first gated using side scatter (SSC) and PerCP-CD3, and then Th1/ Th2 cells were determined as CD4-positive T-lymphocytes in CD8-negative cells, with 2,000 cells being counted. The cells positive for IL-6, IFN, IL-4, IL-10, TNF and IL-2 were analyzed with CELLQuest software.

Statistical analysis. Where appropriate, the data are expressed as the means \pm SD. Significance testing was performed using a paired t-test for the comparison of patients prior to and following treatment, and an unpaired t-test for the comparison of patients and healthy controls. $\mathrm{P}<0.05$ was considered to indicate statistically significant differences. Correlation analyses were carried out with Graphpad Instat statistical software, and a correlation coefficient was considered to be statistically significant when $\mathrm{P}<0.05$.

\section{Results}

Patient characteristics. There were $22 \mathrm{CHB}$ patients and 10 healthy volunteers enrolled in this study. The mean age was $45.9 \pm 8.1$ years for $\mathrm{CHB}$ patients, with an average length of HBV infection of $10.3 \pm 1.6$ years, and $45.1 \pm 6.6$ years in the 
Table I. Characteristics and levels of ALT, AST and HBV DNA of 22 CHB patients prior to and following ADV treatment.

\begin{tabular}{|c|c|c|c|c|c|c|c|c|c|c|c|c|c|c|}
\hline \multirow[t]{2}{*}{ No. } & \multirow[t]{2}{*}{ Gender } & \multirow{2}{*}{$\begin{array}{c}\text { Age } \\
\text { (years) }\end{array}$} & \multicolumn{4}{|c|}{ ALT (U/l) } & \multicolumn{4}{|c|}{ AST (U/l) } & \multicolumn{4}{|c|}{ HBV DNA ( $x 10^{3}$ copies $\left./ \mathrm{ml}\right)$} \\
\hline & & & $0^{\mathrm{a}}$ & $4 w^{a}$ & $12 \mathrm{w}^{\mathrm{a}}$ & $24 \mathrm{w}^{\mathrm{a}}$ & $0^{\mathrm{a}}$ & $4 w^{a}$ & $12 w^{a}$ & $24 \mathrm{w}^{\mathrm{a}}$ & $0^{\mathrm{a}}$ & $4 w^{a}$ & $12 w^{a}$ & $24 \mathrm{w}$ \\
\hline 1 & M & 43 & 272.5 & 78.5 & 25.3 & 20.7 & 137.1 & 68.8 & 28.2 & 24.8 & 1,500 & 260 & LDL & 3.50 \\
\hline 2 & $\mathrm{M}$ & 47 & 199.5 & 122.0 & 50.0 & 29.1 & 123.0 & 122.7 & 31.6 & 23.7 & 10,800 & 520 & 431 & 0.70 \\
\hline 3 & $\mathrm{~F}$ & 40 & 109.6 & 58.6 & 46.1 & 11.8 & 60.9 & 72.7 & 34.4 & 22.0 & 10,200 & 9,400 & 4.23 & 1,500 \\
\hline 4 & M & 46 & 98.0 & 44.3 & 19.1 & 24.1 & 23.7 & 35.6 & 17.5 & 16.4 & 33,000 & 670 & 4410 & LDL \\
\hline 5 & M & 49 & 127.0 & 69.7 & 37.6 & 26.0 & 76.7 & 65.5 & 25.4 & 24.8 & 1,870 & 7,430 & LDL & LDL \\
\hline 6 & M & 47 & 84.8 & 42.8 & 30.3 & 25.8 & 20.3 & 40.2 & 24.3 & 24.3 & 20.4 & LDL & LDL & LDL \\
\hline 7 & $\mathrm{~F}$ & 56 & 77.5 & 56.9 & 34.8 & 25.8 & 62.1 & 35.2 & 27.7 & 27.7 & 4,260 & 1,260 & LDL & LDL \\
\hline 8 & M & 39 & 112.4 & 87.2 & 28.7 & 23.0 & 83.0 & 45.3 & 30.5 & 26.5 & 504.0 & 38.7 & LDL & LDL \\
\hline 9 & $\mathrm{~F}$ & 48 & 71.9 & 79.1 & 18.0 & 25.2 & 64.6 & 87.1 & 22.0 & 26.0 & 360.0 & 70.3 & LDL & LDL \\
\hline 10 & M & 41 & 107.3 & 82.6 & 33.7 & 33.6 & 35.6 & 58.6 & 27.7 & 25.4 & 30.3 & LDL & LDL & 0.475 \\
\hline 11 & $\mathrm{M}$ & 40 & 211.3 & 113.5 & 69.1 & 43.1 & 78.4 & 92.4 & 36.7 & 28.8 & 13,600 & 446 & 1.16 & LDL \\
\hline 12 & M & 61 & 77.0 & 78.9 & 23.0 & 22.4 & 64.9 & 45.7 & 28.2 & 28.8 & 4,880 & 117 & LDL & LDL \\
\hline 13 & $\mathrm{M}$ & 39 & 106.2 & 56.9 & 68.6 & 43.7 & 90.0 & 58.9 & 53.0 & 29.3 & 381.0 & 123 & 4.01 & LDL \\
\hline 14 & M & 53 & 445.6 & 125.5 & 39.3 & 37.5 & 51.9 & 94.3 & 29.3 & 27.1 & 40.4 & 2.3 & LDL & LDL \\
\hline 15 & M & 60 & 125.3 & 78.1 & 32.6 & 58.8 & 83.0 & 81.6 & 38.4 & 45.7 & 3.17 & LDL & LDL & LDL \\
\hline 16 & M & 54 & 93.5 & 47.8 & 55.6 & 61.1 & 58.6 & 41.1 & 45.7 & 45.1 & 388.0 & LDL & LDL & LDL \\
\hline 17 & $\mathrm{~F}$ & 37 & 107.3 & 48.1 & 41.6 & 20.2 & 60.4 & 34.9 & 44.6 & 27.7 & 85.0 & 4.3 & LDL & LDL \\
\hline 18 & $\mathrm{~F}$ & 43 & 332.7 & 89.6 & 13.5 & 11.8 & 221.3 & 27.8 & 17.5 & 14.1 & 75.7 & 1.57 & LDL & 0.54 \\
\hline 19 & M & 30 & 265.8 & 43.7 & 16.3 & 10.1 & 68.8 & 33.4 & 22.0 & 13.0 & 64.6 & LDL & 1.50 & LDL \\
\hline 20 & $\mathrm{M}$ & 43 & 346.1 & 132.0 & 49.4 & 29.1 & 125.8 & 58.5 & 26.0 & 17.5 & 580.0 & 103 & 2.10 & LDL \\
\hline 21 & $\mathrm{~F}$ & 48 & 156.8 & 58.9 & 24.7 & 20.2 & 58.1 & 45.1 & 22.0 & 18.1 & 7,630 & 314 & LDL & LDL \\
\hline 22 & M & 46 & 194.0 & 33.4 & 15.7 & 12.3 & 136.0 & 24.9 & 14.0 & 22.6 & 247.0 & 8.07 & LDL & LDL \\
\hline
\end{tabular}

${ }^{a}$ Analysis time point of pre-treatment (0), post 4 weeks ( $\left.4 \mathrm{w}\right)$, post 12 weeks (12 w) and post 24 weeks (24 w), with the ADV treatment. LDL, lower detection limit (300 copies/ml for Shenzhen PG Biotech kit).

healthy group; there was no significant difference between these two groups $(\mathrm{P}=0.77)$. Detailed characteristics of the 22 patients are shown in Table I.

Cytokine levels of recruited participants. The results of cytokine analyses of $22 \mathrm{CHB}$ patients and 10 healthy volunteers are shown in Fig. 1. The levels of IL-2, IFN- $\gamma$, TNF- $\alpha$, IL-4, IL-6, IL-10 and AST in the serum samples of 22 patients were quantified prior to treatment and three times following initiation of ADV treatment. Prior to ADV treatment, the levels of the analyzed cytokines were significantly lower in CHB patients compared to healthy controls $(\mathrm{P}<0.001$ for all cytokines). Following ADV treatment, the levels of IL-2, IFN- $\gamma$, TNF- $\alpha$, IL-4, IL-6 and IL-10 increased significantly in a time-dependent manner, as monitored at weeks 4, 12 and 24 after treatment. These results indicate that ADV enhances the immune activity of Th1/Th2 in CHB patients.

Correlations between cytokine levels and liver functions in CHB patients. The correlation analyses between cytokine and AST levels were determined and the results are shown in Table II, indicating that the majority of the cytokine levels at various times following ADV treatment were not correlated with the AST levels of patients, and that only the expression of IL-2, IFN, TNF and IL-10 at 12 weeks following treatment showed negative correlations with the AST levels (Table II; $\mathrm{P}<0.05)$. There were no correlations between ALT and cytokine levels at any time points following the initiation of ADV treatment (Table III).

Correlations between cytokine levels and HBV DNA levels in $C H B$ patients. The correlations between cytokine levels and HBV DNA levels in the serum of $\mathrm{CHB}$ patients were also determined at various times following ADV treatment. As shown in Table IV, there were no correlations between the majority of cytokine and HBV DNA levels, with the exception of the TNF- $\alpha$ level at 24 weeks following ADV treatment, showing a positive correlation with HBV DNA levels.

Correlations between cytokine levels and clinical response in $\mathrm{CHB}$ patients. The clinical responses of the $\mathrm{CHB}$ patients to the ADV treatment were classified into three levels, according to the changes in HBV DNA, HBeAg and ALT: complete response, all three values had decreased; no response, none of the three values had changed; partial response, changes were observed in any one of the three values. The clinical response of each patient was evaluated at 12 or 24 weeks following ADV treatment. The correlations of cytokines and clinical 
Th1
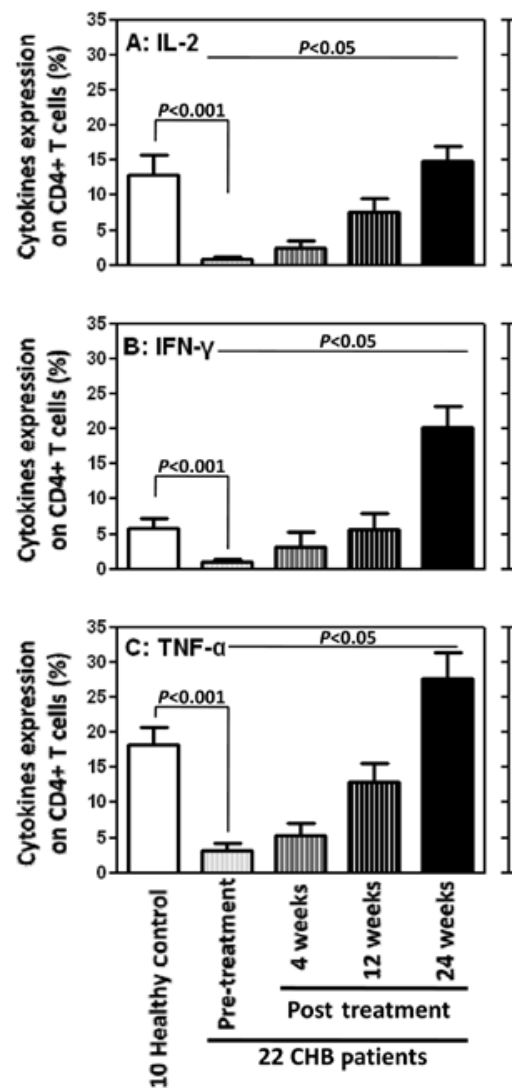

Th2
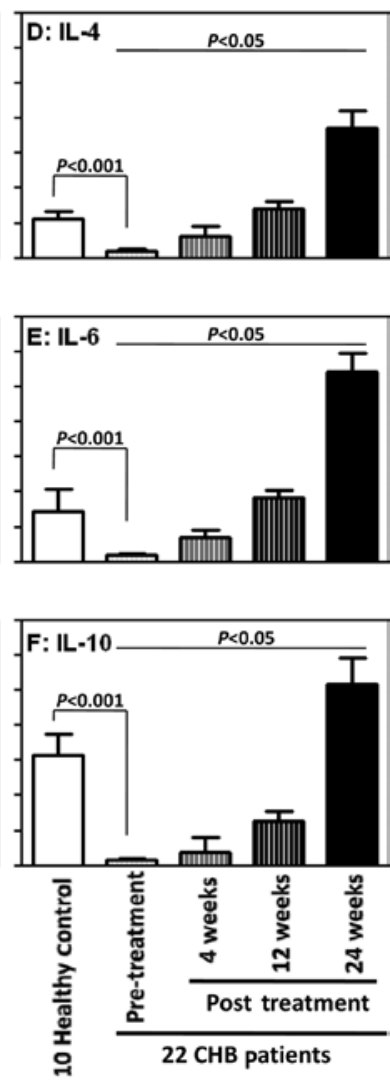

Figure 1. Levels of IL-2, IFN- $\gamma$, TNF- $\alpha$, IL-4, IL-6 and IL-10 in 10 healthy subjects and 22 chronic hepatitis $\mathrm{B}$ (CHB) patients prior to and following ADV treatment. responses were analyzed and the results are shown in Table V. Following 12 weeks of ADV treatment, 14 patients showed complete clinical response and their cytokine levels increased significantly compared to the levels prior to treatment $(\mathrm{P}<0.05)$; 8 patients showed a partial clinical response, and IL-4 and IL-6 expression levels increased significantly (Table V; $\mathrm{P}<0.05$ ). At 24 weeks following ADV treatment, the cytokine levels of 18 patients with a complete clinical response were significantly higher than those at 12 weeks post-ADV treatment $(\mathrm{P}<0.05)$, while only the IL-6 levels in 4 patients with a partial clinical response were significantly higher than those at 12 weeks post-ADV treatment (Table V; $\mathrm{P}<0.05$ ). At 12 and 24 weeks following ADV treatment, the cytokine levels in patients with a complete clinical response were significantly higher than those in patients with a partial clinical response (Table V; $\mathrm{P}<0.05)$.

\section{Discussion}

ADV has a broad-spectrum of antiviral activity, targeting herpesvirus, retroviruses and hepadnaviruses $(7,20)$ and potently inhibits the replication of wild-type HBV and lamivudine-resistant strains (3). In this study, the serum HBV DNA levels in the majority $(77.3 \%, 17 / 22)$ of $\mathrm{CHB}$ patients were decreased to the levels less than the detection limit following 24 weeks of ADV treatment, although certain patients, e.g., Patient 3, had no or little response to the ADV treatment, which may be associated with ADV resistance (21). The ALT and AST levels were also reduced significantly following 24 weeks of ADV treatment. Our data were in agreement with the report

Table II. Correlation analyses between cytokines and AST pre- or post-ADV treatment.

\begin{tabular}{|c|c|c|c|c|c|c|}
\hline \multirow[t]{2}{*}{ Groups } & \multicolumn{6}{|c|}{ Correlation coefficient with AST } \\
\hline & IL-2 & IFN & TNF & IL-4 & IL-6 & IL-10 \\
\hline Pre-treatment & 0.122 & 0.238 & 0.243 & 0.147 & 0.271 & 0.129 \\
\hline Post 4 weeks & 0.061 & -0.048 & 0.095 & 0.021 & 0.036 & -0.106 \\
\hline Post 12 weeks & $-0.423^{\mathrm{a}}$ & $-0.482^{\mathrm{a}}$ & $-0.465^{\mathrm{a}}$ & 0.380 & -0.069 & $-0.471^{\mathrm{a}}$ \\
\hline Post 24 weeks & -0.026 & -0.299 & -0.307 & -0.053 & -0.201 & -0.226 \\
\hline
\end{tabular}

${ }^{\mathrm{a}} \mathrm{P}<0.05$. Numbers are Pearson's correlation coefficients (r) calculated by the Graphpad Instat statistical software.

Table III. Correlation analyses between cytokines and ALT pre- or post-ADV treatment.

\begin{tabular}{lccccrr}
\hline Groups & \multicolumn{5}{c}{ Correlation coefficient with ALT } \\
\cline { 2 - 6 } & IL-2 & IFN & TNF & IL-4 & IL-6 & IL-10 \\
\hline Pre-treatment & 0.080 & 0.016 & 0.159 & 0.019 & 0.014 & -0.073 \\
Post 4 weeks & 0.037 & -0.143 & -0.265 & -0.217 & -0.018 & -0.093 \\
Post 12 weeks & -0.099 & -0.350 & -0.227 & -0.027 & -0.148 & -0.181 \\
Post 24 weeks & 0.020 & -0.187 & -0.367 & -0.012 & -0.089 & -0.054 \\
\hline
\end{tabular}

Numbers are Pearson's correlation coefficients (r) calculated by the Graphpad Instat statistical software. No significant correlation of the six cytokines with ALT was found in any stage. 
Table IV. Correlation analyses between cytokines and HBV DNA levels in patients pre- or post-ADV treatment.

\begin{tabular}{lcccrr}
\hline Groups & \multicolumn{5}{c}{ Correlation coefficient with HBV DNA levels } \\
\cline { 2 - 6 } & IL-2 & IFN & TNF & IL-4 & IL-6 \\
\hline Pre-treatment & -0.026 & -0.299 & $-0.307^{\mathrm{a}}$ & -0.053 & -0.201 \\
Post 4 weeks & 0.034 & -0.884 & 0.124 & -0.075 & -0.019 \\
Post 12 weeks & 0.124 & -0.055 & 0.283 & -0.184 & -0.038 \\
Post 24 weeks & -0.103 & -0.197 & $0.625^{\mathrm{a}}$ & -0.025 & -0.278 \\
\hline
\end{tabular}

${ }^{a} \mathrm{P}<0.01$. Numbers are Pearson's correlation coefficients ( $\mathrm{r}$ ) calculated by the Graphpad Instat statistical software.

Table V. Correlation analyses between cytokines levels and clinical responses to ADV treatment.

\begin{tabular}{|c|c|c|c|c|c|c|c|c|}
\hline $\begin{array}{l}\text { Time (post- } \\
\text { treatment) }\end{array}$ & Groups & Cases & IL-2 & IFN & $\mathrm{TNF}$ & IL-4 & IL-6 & IL-10 \\
\hline \multirow[t]{3}{*}{12 weeks } & Healthy subjects & 10 & $12.92 \pm 2.81$ & $5.79 \pm 1.53$ & $18.2 \pm 2.62$ & $5.71 \pm 1.03$ & $7.27 \pm 3.11$ & $15.85 \pm 3.01$ \\
\hline & $\begin{array}{l}\text { CHB with } \\
\text { complete response }\end{array}$ & 14 & $8.07 \pm 2.07^{\mathrm{a}}$ & $12.17 \pm 3.75^{\mathrm{a}}$ & $17.12 \pm 4.69^{\mathrm{a}}$ & $12.18 \pm 2.59^{\mathrm{a}}$ & $14.99 \pm 3.46^{\mathrm{a}}$ & $7.80 \pm 1.90^{\mathrm{a}}$ \\
\hline & $\begin{array}{l}\text { CHB with } \\
\text { partial response }\end{array}$ & 8 & $6.25 \pm 2.30$ & $6.56 \pm 1.65^{\mathrm{a}}$ & $9.10 \pm 1.58^{\mathrm{a}}$ & $9.04 \pm 2.50^{\mathrm{a}}$ & $2.66 \pm 0.82^{\mathrm{a}}$ & $12.49 \pm 4.05^{\mathrm{a}}$ \\
\hline \multirow[t]{2}{*}{24 weeks } & $\begin{array}{l}\text { CHB with } \\
\text { complete response }\end{array}$ & 18 & $16.2 \pm 2.37^{\mathrm{b}, \mathrm{c}}$ & $22.2 \pm 3.29^{b, c}$ & $30.0 \pm 4.09^{\mathrm{b}, \mathrm{c}}$ & $19.3 \pm 2.42^{b, c}$ & $27.5 \pm 3.16^{\mathrm{b}, \mathrm{c}}$ & $25.1 \pm 3.00^{b, c}$ \\
\hline & $\begin{array}{l}\text { CHB with } \\
\text { partial response }\end{array}$ & 4 & $8.93 \pm 5.17$ & $10.9 \pm 5.32$ & $17.5 \pm 8.08$ & $15.5 \pm 8.91$ & $25.9 \pm 4.69^{\mathrm{a}, \mathrm{c}}$ & $25.5 \pm 11.10$ \\
\hline
\end{tabular}

${ }^{\mathrm{a}} \mathrm{P}<0.05$, compared to pre-treatment; ${ }^{\mathrm{b}} \mathrm{P}<0.05$, compared to 12 weeks post-treatment; ${ }^{\mathrm{C}} \mathrm{P}<0.05$, compared to healthy control. Values represent the means $\pm \mathrm{SD}$ in units $(\mathrm{ng} / \mathrm{ml})$.

of Marcellin et al (1), which showed that ADV reduces serum HBV DNA and ALT levels.

In the present study, expression levels of six cytokines were quantified by flow cytometry, a technique that is now routinely available in the majority of clinical laboratories worldwide $(21,22)$. Prior to ADV treatment, the expression levels of the six cytokines analyzed in the CHB patients were significantly lower than those in healthy controls. However, there were no differences in the expression levels between Th1 and Th2 cells in our study, which was different from the findings of Milich (23) and Marinos et al (24). The difference may be associated with the detection techniques for the cellular cytokines. Following ADV treatment, the expression levels of IL- 2 , IFN- $\gamma$, TNF- $\alpha$, IL-4, IL-6 and IL-10 significantly increased at 4, 12 and 24 weeks, in a time-dependent fashion, indicating that ADV treatment greatly enhances the cellular immune function in CHB patients.

When we evaluated the correlation between the clinical response to ADV treatment and cytokine changes in the $\mathrm{CHB}$ patients, we found mixed results. The levels of HBV DNA, ALT and AST showed no correlation with the cytokines examined. Considering that the liver function assays reflect the state of liver cells and Th1/Th2 cells are only a part of the immune system of the patients, we speculate that there are significant differences in the patterns of virus clearance and pathological changes of liver cells in CHB patients (25). Following 12 weeks of ADV treatment, the majority of patients $(14 / 22,63.6 \%)$ had a complete clinical response, and the expression levels of the six cytokines were significantly enhanced compared to those prior to treatment. Following 24 weeks of ADV treatment, the levels of the six cytokines in the 18 complete clinical response patients were further elevated compared to those following 12 weeks of treatment. The remaining 4 patients with a partial response may be associated with ADV resistance as mentioned above.

In conclusion, our results show that $\mathrm{ADV}$ treatment in $\mathrm{CHB}$ patients affects the expression of IL- 2 , IFN- $\gamma$, TNF- $\alpha$, IL-4, IL-6 and IL-10 and improves the immunity of T-helper cells. Since anti-virus immune response is a significant method of virus clearance in the body, our findings provide a new mechanism of action for ADV therapy. Further studies are required to understand the implication of the results in clinical patient care, as well as the impact of ADV treatment on other immune cells in CHB patients.

\section{Acknowledgements}

This study was supported in part by the National Natural Science Foundation of China (Grant no. 30571642).

\section{References}

1. Marcellin P, Chang TT, Lim SG, et al: Adefovir dipivoxil for the treatment of hepatitis B e antigen-positive chronic hepatitis B. N Engl J Med 348: 808-816, 2003. 
2. Liang X, Bi S, Yang W, et al: Epidemiological serosurvey of hepatitis B in China-declining HBV prevalence due to hepatitis B vaccination. Vaccine 27: 6550-6557, 2009.

3. Van der Molen RG, Sprengers D, Biesta PJ, Kusters JG and Janssen HL: Favorable effect of adefovir on the number and functionality of myeloid dendritic cells of patients with chronic HBV. Hepatology 44: 907-914, 2006.

4. Schiff E, Neuhaus P, Tillmann H, Samuel D, Terrault N and Marcellin P: Safety and efficacy of adefovir dipivoxil for the treatment of lamivudine resistant $\mathrm{HBV}$ in patients post liver transplantation. Hepatology 34: 446A, 2001.

5. Hadziyannis SJ, Tassopoulos NC, Heathcote EJ, et al: Adefovir dipivoxil for the treatment of hepatitis $\mathrm{B}$ e antigen-negative chronic hepatitis B. N Engl J Med 348: 800-807, 2003.

6. Peters MG, Hann Hw H, Martin P, et al: Adefovir dipivoxil alone or in combination with lamivudine in patients with lamivudineresistant chronic hepatitis B. Gastroenterology 126: 91-101, 2004

7. Delaugerre C, Marcelin AG, Thibault V, et al: Human immunodeficiency virus (HIV) Type 1 reverse transcriptase resistance mutations in hepatitis B virus (HBV)-HIV-coinfected patients treated for HBV chronic infection once daily with 10 milligrams of adefovir dipivoxil combined with lamivudine. Antimicrob Agents Chemother 46: 1586-1588, 2002.

8. Lee M, Lee SK, Son M, Cho SW, Park S and Kim HI: Expression of Th1 and Th2 type cytokines responding to HBsAg and HBxAg in chronic hepatitis B patients. J Korean Med Sci 14: 175-181, 1999.

9. Grewe M, Bruijnzeel-Koomen CA, Schopf E, et al: A role for Th1 and Th2 cells in the immunopathogenesis of atopic dermatitis. Immunol Today 19: 359-361, 1998.

10. Lechmann M, Woitas RP, Langhans B, et al: Decreased frequency of HCV core-specific peripheral blood mononuclear cells with type 1 cytokine secretion in chronic hepatitis C. J Hepatol 31: 971-978, 1999.

11. Li QQ and Bever CT: Th1 cytokines stimulate RANTES chemokine secretion by human astroglial cells depending on de novo transcription. Neurochem Res 26: 125-133, 2001.

12. Mosmann TR and Coffman RL: TH1 and TH2 cells: different patterns of lymphokine secretion lead to different functional properties. Annu Rev Immunol 7: 145-173, 1989.

13. Yu Y, Wu H, Tang Z and Zang G: CTLA4 silencing with siRNA promotes deviation of Th1/Th2 in chronic hepatitis B patients. Cell Mol Immunol 6: 123-127, 2009.

14. Viallard JF, Pellegrin JL, Ranchin V, et al: Th1 (IL-2, interferon-gamma (IFN-gamma)) and Th2 (IL-10, IL-4) cytokine production by peripheral blood mononuclear cells (PBMC) from patients with systemic lupus erythematosus (SLE). Clin Exp Immunol 115: 189-195, 1999.
15. Nagai H, Miyaki D, Matsui T, et al: Th1/Th2 balance: an important indicator of efficacy for intra-arterial chemotherapy. Cancer Chemother Pharmacol 62: 959-963, 2008.

16. Naugler WE, Sakurai T, Kim S, et al: Gender disparity in liver cancer due to sex differences in MyD88-dependent IL-6 production. Science 317: 121-124, 2007.

17. Bertoletti A, D'Elios MM, Boni C, et al: Different cytokine profiles of intrahepatic $\mathrm{T}$ cells in chronic hepatitis $\mathrm{B}$ and hepatitis C virus infections. Gastroenterology 112: 193-199, 1997.

18. Lorentz K: Approved recommendation on IFCC methods for the measurement of catalytic concentration of enzymes part 9. IFCC method for $\alpha$-amylase (1, 4- $\alpha$-D-Glucan 4-Glucanohydrolase EC 3.2.1.1). International Federation of Clinical Chemistry and Laboratory Medicine (IFCC). Committee on Enzymes. Clin Chem Lab Med 36: 185-203, 1998.

19. Bergmeyer H, Hørder M and Rej R: International Federation of Clinical Chemistry (IFCC) Scientific Committee, Analytical Section: Approved recommendation (1985) on IFCC methods for the measurement of catalytic concentration of enzymes. Part 3. IFCC method for alanine aminotransferase (L-alanine: 2-oxoglutarate aminotransferase, EC 2.6.1.2). J Clin Chem Clin Biochem 24: 481-495, 1986.

20. Pauwels R, Balzarini J, Schols D, et al: Phosphonylmethoxyethyl purine derivatives, a new class of anti-human immunodeficiency virus agents. Antimicrob Agents Chemother 32: 1025-1030, 1988.

21. Angus $\mathrm{P}$, Vaughan R, Xiong S, et al: Resistance to adefovir dipivoxil therapy associated with the selection of a novel mutation in the HBV polymerase. Gastroenterology 125: 292-297, 2003.

22. North M, Ivory K, Funauchi M, Webster A, Lane A and Farrant J: Intracellular cytokine production by human CD4 and CD8 T cells from normal and immunodeficient donors using directly conjugated anti-cytokine antibodies and three-colour flow cytometry. Clin Exp Immunol 105: 22, 1996.

23. Milich D: Influence of T-helper cell subsets and cross-regulation in hepatitis B virus infection. J Viral Hepat 4: 48-59, 1997.

24. Marinos G, Rossol S, Carucci P, et al: Immunopathogenesis of hepatitis B virus recurrence after liver transplantation. Transplantation 69: 559, 2000.

25. Xing TJ, Zhang L, Luo KX, et al: Intrahepatic expression of Th1/ Th2 cytokine in HBV infection and its clinical significance. Med J Chin People's Liberation Army 25: 235-237, 2000. 